\title{
PRODUCTION OF PHENOL-OXIDASES AND PEROXIDASES BY FUNGI ISOLATED FROM IRRIGATED RICE
}

\author{
Célia Maria Maganhotto de Souza Silva*; Itamar Soares de Melo; Rosana Faria Vieira \\ Embrapa Meio Ambiente, Jaguariúna, SP, Brasil.
}

\begin{abstract}
This paper corresponds to an "extended abstract" selected for oral presentation in the $22^{\text {nd }}$ Brazilian Congress of Microbiology, held in Florianópolis, SC, Brazil, in November 17-20, 2003
\end{abstract}

\begin{abstract}
The aim of this work was to study the potential of fungus strains considered as prospective degraders for the herbicides quinclorac and propanil, for ligninolytic enzyme production. Eight fungal strains were grown in King's B liquid culture medium supplemented with $0.05 \%$ Remazol Brilliant Blue R (RBBR) and in liquid culture medium containing wheat bran as substrate. The enzymatic system assessment were: lignin peroxidase, manganese peroxidase and laccases. Results indicated differential patterns of ligninolytic enzyme production; the highest enzymatic activities were related to the production of lignin peroxidase. Among the strains, two (P3SA1F and P11SA2F) showed RBBR discoloration, suggesting the possibility of their application in bioremediation studies.
\end{abstract}

Key words: ligninolytic enzymes, laccases, Remazol Brilliant Blue R.

\section{INTRODUCTION}

From an economic and social standpoints, irrigated rice is one of the most important crop in southern Brazil. Almost all rice growers need to use herbicides to control weeds. Quinclorac and propanil are the herbicides utilized for this purpose. Biodegradation is a viable alternative to reduce the concentration of these compounds in the ecosystem. The enzymatic complex that degrades lignin has been described as responsible for the degradation of several organic pollutants (5). This trait is an advantage when using ligninolytic fungi for bioremediation. A simple and quick method to select fungi with ligninolytic activity is the use of polymeric dyes that are similar to the lignin polymer. Due to its industrial importance, the most utilized dye is Remazol Brilliant Blue R (RBBR).

Considering that the sediment of irrigated rice producing areas may present a mixture of agrochemical and crop residues, this work proposed to study the potential ligninolytic enzyme production by fungal strains obtained from rhizozphere of rice plants. These strains can be considered potential degraders of the herbicides propanil and quinclorac.

\section{MATERIALS AND METHODS}

The fungal strains were isolated from the soil rizosphere of rice in farm of rice crops in Santa Catarina. Initially, the fungi were grown in solid culture medium containing malt extract, supplemented with the herbicides propanil and quinclorac, in order to isolate strains that would be degraders and/or resistant to these compounds. Eight strains were selected (Table 1), and transferred (three $9 \mathrm{~mm}$ discs) to Erlenmeyer flasks containing liquid culture medium, prepared for the following analytical determinations: enzymatic activities and oxidation of the Remazol Brilliant Blue R (RBBR) dye.

\section{Enzymatic analyses}

The strains were grown in liquid culture medium $(4.5 \mathrm{~g}$ wheat bran; $1.5 \mathrm{~g}$ yeast extract; $1 \mathrm{~g}$ glucose; $0.5 \mathrm{~g}$ ammonia chloride;

*Corresponding author. Mailing address: Embrapa Meio Ambiente, Rodovia SP-340, km 127,5, s/n, Caixa Postal 69. 13820-000 Jaguariúna, SP, Brasil. Tel.: (+5519) 3867-8763. Fax (+5519) 3867-8740. E-mail: celia@cnpma.embrapa.br 
$100 \mathrm{~mL}$ salts solution; $900 \mathrm{~mL}$ distilled water), and incubated for 7 days at $30^{\circ} \mathrm{C}$ in a static culture system. They were then filtered and submitted to determination of the enzymatic activities of lignin peroxidase, manganese peroxidase and laccases. The lignin peroxidase (LiP) activity was evaluated by UV spectrometry of the veratryl aldehyde produced $\left({ }^{\mathrm{TM}} 310=9,300 \mathrm{M}^{-1}\right.$ $\mathrm{cm}^{-1}$ ) during veratryl alcohol oxidation. The manganese peroxidase $(\mathrm{MnP})$ was measured at $610 \mathrm{~nm}\left({ }^{\mathrm{TM}}{ }_{610}=4,460 \mathrm{M}^{-1} \mathrm{~cm}^{-1}\right)$ using the methodology described by Kuwahara et al. (3). The laccase activity was also measured by spectrophotometry, as o-dianisidine oxidation at $525 \mathrm{~nm}\left({ }^{\mathrm{TM}}{ }_{525}=65,000 \mathrm{M}^{-1} \mathrm{~cm}^{-1}\right)$. All analyses utilized boiled culture medium as a control. For all enzymes, one activity unit was defined as the amount of enzyme necessary to oxidize $1 \mu \mathrm{mol}$ of substrate per minute.

\section{Oxidation of the RBBR dye}

Strains were grown in King's B liquid culture medium containing proteose-peptone $(10 \mathrm{~g})$, K2HPO4 (1.5g), Mg.SO4.7H2O (1.5g), glycerin (12.45g), distilled water (1L), and $0.05 \%$ Remazol Brilliant Blue R. The flasks were incubated at $30^{\circ} \mathrm{C}$, in the dark, under constant agitation (130rpm), for as long as needed. Decolorization was determined by monitoring the decrease in the absorbance peak at $595 \mathrm{~nm}$. The mycelium was separated by filtration and then weighed. The biomass determination was performed by gravimetry, using oven-drying at $70^{\circ} \mathrm{C}$ until constant weight was achieved.

\section{RESULTS AND DISCUSSION}

The fungi strains presented differentiated ligninolytic enzyme production patterns (Table 1). The highest enzymatic activities detected were related to the production of lignin peroxidase. The maximum detected level was $6.079 \mathrm{U} \mathrm{L}^{-1}$ (P11SA4F strain), followed by $3.332 \mathrm{UL}^{-1}$ (P2SA6F strain). None of the fungi strain was comparable in terms of LiP production to Ganoderma sp.strain GASI3.4 (18.851 $\left.\mathrm{U} \mathrm{L}^{-1}\right)$, used as control.
MnP enzymatic activity was observed in three strains only, and only one of them (P2SA3F) resulted in a higher concentration $\left(2.765 \mathrm{U} \mathrm{L}^{-1}\right)$ than that obtained with the control strain $\left(1.084 \mathrm{U} \mathrm{L}^{-1}\right)$. The other strains showed very low or none activity. The production of MnP by strain P2SA3F can be considered efficient, especially when compared to activities obtained by Arora et al. (1) with white rot fungi. The activities found for laccase ranged from $0.056 \mathrm{U} \mathrm{L}^{-1}$ to $0.753 \mathrm{U} \mathrm{L}^{-1}$. The strain with the highest laccase production was $\mathrm{P} 2 \mathrm{SA} 3 \mathrm{~F}$, followed by P2SA5F $\left(0.699 \mathrm{U} \mathrm{L}^{-1}\right)$ and P3SA1F $\left(0.609 \mathrm{U} \mathrm{L}^{-1}\right)$. The Ganoderma sp. control strain GASI3.4 showed a much higher activity $\left(6.057 \mathrm{U} \mathrm{L}^{-1}\right)$, thus rendering the other observed activities negligible. However, the values obtained in this work are higher than those obtained for Coriolus versicolor $\left(4.406 \mathrm{U} \mathrm{mL}^{-1}\right)$ and Funalia trogii $\left(4.880 \mathrm{U} \mathrm{mL}^{-1}\right)$ (2), or for Trametes trogii $(0.55 \mathrm{U}$ $\mathrm{mL}^{-1}$ ) when utilizing malt extract as a $\mathrm{C}$ source (4).

Some strains of the studied showed an enzymatic complex capable of decolorizing the Remazol Brilliant Blue R dye. Among the eight strains tested (Table 1), two, P3SA1F and P11SA2F, showed 42 and $47 \%$ decolorization, respectively, although they showed activity for laccase only. When compared to the standard Ganoderma sp. strain GAI3.4, the behavior of these strains was promising, suggesting the possibility of their application in bioremediation studies. Further studies are needed in order to test the efficiency of these strains as degraders, with the objective of exploring the biotechnological potential of such alternative enzyme sources.

\section{RESUMO}

\section{Produção de fenol-oxidases e peroxidases por fungos isolados da cultura de arroz irrigado}

A proposta deste trabalho foi estudar o potencial das linhagens fúngicas, consideradas potenciais degradadoras dos herbicidas quinclorac e propanil, para produção de enzimas

Table 1. Ligninolytic enzyme production and decolorization of Remazol Brilliant Blue R by fungal strains isolated from a rice crop.

\begin{tabular}{|c|c|c|c|c|c|}
\hline \multirow[b]{2}{*}{ Strains } & \multicolumn{3}{|c|}{ Enzymatic activity } & \multirow{2}{*}{$\begin{array}{c}\text { Remazol degradation } \\
(\%)\end{array}$} & \multirow[b]{2}{*}{ Biomass } \\
\hline & Lignin peroxidase & $\begin{array}{l}\text { Manganese } \\
\text { peroxidase }\end{array}$ & Laccase & & \\
\hline P2SA5F & $\mathrm{ND}$ & 0.192 & 0.699 & 6.0 & 0.90 \\
\hline P2SA3F & 3.125 & 2.765 & 0.753 & 4.1 & 0.82 \\
\hline Q4SR1F & 1.136 & ND & 0.056 & 25.0 & 0.83 \\
\hline P3SA1F & ND & ND & 0.609 & 42.1 & 1.50 \\
\hline P2SA6F & 3.332 & ND & 0.530 & 1.3 & 1.13 \\
\hline P11SA4F & 6.079 & ND & ND & 10.3 & 1.23 \\
\hline GASI3.4 (control) & 18.851 & 1.084 & 6.057 & 54.1 & 1.11 \\
\hline
\end{tabular}

$\mathrm{ND}=$ not detected. 
ligninolíticas. Oito linhagens fúngicas foram cultivadas em meio de cultura líquido King's B suplementado com 0,05\% de Remazol Brilliant Blue R (RBBR) e em meio de cultura líquido contendo farelo de trigo como substrato. Os sistemas enzimáticos avaliados foram: lignina peroxidase, manganês peroxidase e lacases. Os resultados demonstraram padrões diferenciados quanto à produção de enzimas ligninolíticas entre as linhagens, sendo que as maiores atividades enzimáticas estiveram relacionadas à produção de lignina peroxidase. Das oito linhagens, duas (P3SA1F e P11SA2F) apresentaram descoloração do RBBR, sugerindo a possibilidade de sua aplicabilicação em estudos de biorremediação

Palavras-chave: enzimas ligninolíticas, lacases, Remazol Brilliant Blur R.

\section{REFERENCES}

1. Arora, D.S.; Chander, M.; Gill, P.K. Involvement of lignin peroxidase, manganes peroxidase and laccase in degradation and selective ligninolysis of wheat straw. Int. Biodeterior. Biodegr., 50:115-120, 2002.

2. Kahraman, S.S.; Gurdal, I.H. Effect of synthetic and natural culture media on laccase production by white rot fungi. Bioresour. Technol., 82:215-217, 2002.

3. Kuwahara, M.; Glenn, J.K.; Morgan, M.A.; Gold, M.H. Separation and characterization of two extracellular $\mathrm{H}_{2} \mathrm{O}_{2}$-dependent oxidases from ligninolytic cultures of Phanerochaete chrysosporium. FEBS Lett., 169:247-250, 1984.

4. Levin, L.; Viale, A.; Forchiassin, A. Degradation of organic pollutants by the white rot basidiomycete Trametes trogii. Int. Biodeterior. Biodegrad., 52:1-5, 2003.

5. Pointing, S.B. Feasibility of bioremediation by white-rot fungi. Appl. Microbiol. Biotechnol., 57:20-33, 2001. 